\title{
Some Problems of Introducing European Credit Transfer System (ECTS) into Non-State Higher Institutions
}

\section{Stepanov Victor Ivanovich}

\author{
Altai Economics and Law Institute, Pr. Krasnoarmeyskiy, 108, Barnaul, Russia, 656015 \\ rector@aeli.altai.ru
}

\section{Doi:10.5901/mjss.2015.v6n5p243}

\section{Abstract}

The article deals with theoretical and organizational problems of introducing European credit transfer system (ECTS) into Russian non-state higher institutions. The author has come to the conclusion that the introduction of ECTS gives rise to a lot of questions on the part of professors and students of higher educational institutions. It is noted in the article that when working out the conception of credit system for Russian higher school it is important to discuss principles of credit assessment of educational curriculum content on the basis of planning the results of its realization. The suggested idea is to give higher institutions an opportunity to work out experimental educational standards within the limits of cycle (and perhaps, course) structure of federal state educational standards.

Keywords: quality of education, non-state sector of higher education, problems of introducing ECTS.

\section{Introduction}

The increase of the quality of education is the most important and acute problem which is being solved by different higher education institutions. Globalisation of the social-economic and cultural processes is connected with the transfer to the innovative economy, based on the informative technologies and growing intellectualisation of main factors of production.

It is mathematically proved that the increase of the rate of people with higher education leads to the growth of work productivity of all the labour force in the region as well as the level of salaries of all the categories of employees [1].

Before the transfer to the market economy the income due to higher education was increasing for $2-4 \%$, but by $2000-2005$ this index was $8-10 \%$ [2].

No wonder that the specific gravity of the young people, who get higher education in the developed countries, is constantly growing. Now there are about 80 million students in the world. According to the forecast, by 2025 the amount of students should be two times bigger. For example, the transfer to the universal higher education is almost completed in Japan.

\section{Analysis of the Problem}

The world system of higher education is not formed yet. Globalisation is contradictory, it cuts the way through the integration of local economic and political associations therefore the regional and integration processes prevail in the sphere of education.

One of them is Bologna process named after the city where in 1999 the Bologna declaration was signed (10 years earlier in the same city Magna Charta Universitatum was signed). It was initiated by the administrations of European universities and then by the education ministers who made it on behalf of professionals who worked in neighbouring countries. Integration of education programmes, development of the common approaches to the education quality assessment and defining of certain units of measurement, named "credits", were needed. Bologna process is actively developing and its intermediate results are constantly being monitored and fixed in the international documents (Prague (2001), Berlin (2003), Bergen (2005), London (2007), Libnah (2009), Budapest-Vienna (2010), Bucharest (2012) [3].

In 1991 Commission of European Communities published the Memorandum of higher education, which contained the priorities of development and transformation of the higher schools of European countries corresponding to the provisions of the Sorbonne and Bologna Declarations [4].

The Bologna Declaration describes this problem as "the assistance to the European collaboration in the sphere of quality assessment by means of development of equitable criteria and methods" [5]. 
In communique, accepted in accordance to the results of the European education ministers meeting on May, 2007, the leading role of higher education institutions as the centres of "education, science, art and knowledge transfer" is underlined [6].

In communique of the European education ministers conference of 2009 it was stated: "We accept the key role of the higher education for the successful solving of the existing problems and for further socio-cultural development of our societies. Therefore we think that the state investments in higher education are of greatest importance" [7].

During the last conference the education ministers of 47 countries stated that one of the main directions of their activity for 2012-2015 would be the provision of the implementation of qualification borders, ECTS and Official transcript, based on the results of education.

The main goal of the Bologna process is the provision of transparency of national education systems on the basis of recommendations and procedures by means of provision of maximum coordinated information while preserving the peculiarities of education systems of every participating country.

Integration of the Russian higher education system into the world system of higher education while preserving and developing of its achievements and traditions is the main principle of the state policy. State programme of education development requires a significant expansion of export of the Russian education including the creation of the network of interuniversity representatives and branches in the countries of neighbouring countries and beyond, involvement of foreign citizens in the studying in Russian higher education institutions. The solving of this task is possible only with the increasing of the competitive ability of Russian professional education on the international market of education services as well as with the provision of opportunities for Russian students and graduates of education institutions to participate in the system of international continuous education.

The scientific university community of Russia, which signed the Bologna Declaration in 2003, now actively discusses the goals and principles of the analysed process. For example, content and Official transcripts. The participants of the Bologna process decided to give Official transcripts to every graduate free of charge using one of the widely spread European languages, they also decided to observe the Lisbon Convention concerning the recognition of documents of higher education of 1997. Russia has ratified the Lisbon convention; however we still have no clear differentiation of the concepts of academic and professional qualifications [8].

On the 15th of February 2005 a decree \#40 by the Ministry of Education of Russia "About the implementation of the provisions of the Bologna Declaration in the system of higher professional education of the Russian Federation" was accepted.

On the 25th of April of the same year there was issued a decree \# 126 of the Ministry of Education and Science of the Russian Federation "About About the main higher education institutions and organisations of the Russian Federation involved into the implementation of the main goals of higher professional education system development in accordance with the Bologna declaration in higher education institutions which coordinate the implementation of main goals of higher professional education development in the regions of the Russian Federation according to the Bologna Declaration".

In October of 2007 there was accepted a Federal Law "About the implementation of changes to the individual legislative acts of the Russian Federation (in the part of setting of the levels of higher professional education)".

On the 17th of November 2008 the enactment \#1662-p of the Parliament of the Russian Federation approved the Concept of long-term social-economic development of the Russian Federation for the period up to 2020.

On the 10th of February 2009 there was accepted a Federal Law \# 18-\$3 "About the implementation of changes into the individual legislative acts of the Russian Federation concerning the issues of activity of the federal universities".

The Plan of actions for implementation of the provisions of the Bologna Declaration in the system of higher professional education of the Russian Federation for 2005-2010 included:

- The problem of the education quality and development of equitable methods and criteria of education quality assessment;

- Creation of the system of equitable criteria, methods and techniques of education quality assessment with the aim of providing harmonization of the Russian system of education quality assessment with the European systems;

- Development of the method of state accreditation of individual education programmes of higher professional education;

- Assistance to the Russia's entering the European Association for Quality Assurance in Higher Education ENQA.

Sub-item 5 item 1 article 3 of the Federal Lawof December 29, 2012 № 273- $\$ 3$ «About the education in the Russian Federation» declared the priority of the state policy in the sphere of education related to the creation of favourable conditions for integration of the Russian education systems into the education systems of other countries on 
the equal and mutually beneficial basis [9].

Evaluating the prospects of implementation of the Bologna process requirements in the Russian education system, we can find different statements in the literature [10]. There is a problem of implementation of different provisions of the Bologna Declaration by the Russian higher education institutions.

Students and teachers have a lot of complications with the recognition of the test, review of the periods of education, acquired by the students in other higher education institutions, including foreign ones. This problem is especially acute for the private education organisations of higher education since they often become the objects of spot checks, evaluation by experts during the accreditation expertise.

Introduction of ECTS awakes a lot of questions raised not only by teachers and students of higher education organisations of the Russian Federation, but also those of the republic of Kazakhstan [11].

The credit system was created in Europe as a means for providing the mobility of students (European Credit Transfer System - ECTS) which guaranteed the transformation from transferable one into accumulative one. This rule generally corresponds to the traditions of the Russian higher school to fix not only the academic progress for each discipline in the Official transcript but also the duration of education. Nevertheless the Credit system arises different disputes.

In Europe there exists an understanding of quantitative parameters of a "credit". In order to lead the Russian Official transcript to the correspondence to the requirements of Diploma Supplement ECTS is used, one should define the parameters of academic qualification and provide the accuracy of translation from Russian of all the names of disciplines and other types of education activity. According to the opinion of the scientists, the conversion of the Russian FSES HVE from academic hours into credits is mainly a technical task. More difficult is the task of transformation of the federal state education standards into such conditional "credits" which take into account comprehensive minimum of knowledge, skills and abilities not i hours (time spent in classrooms), but also can learn the material on their own (remote education, external study etc.).

European experience is based of the unification of the "quantity of education" in the discipline modules, divisible into five credits. An academic year should contain maximum 12 different disciplines (60 credits in total). For Finland, Sweden and Latvia it is 40 credits but 1 national credit corresponds to 1.5 ECTS credits. Russia has 100-point system with the coefficient of conversion into ECTS. However there are another models.

European model as well as Asia-pacific model is mainly oriented to the recognition of credits with the aim of providing academic mobility; American USCS (United States Credit System) and English CATS (Credit Accumulation and Transfer System) - to the accumulation of credits.

Credits-recognition systems of the European universities are based on the understanding of a credit as a unit of assessment of labour inputs for the understanding of an education programme. Credits-accumulative systems define a credit as a unit of results assessment (knowledge, skills and abilities). Guarantees of transformation of ECTS from the transferable into accumulative system is declared, but the practice of the European education has no clear definition of the this technology.

According to the opinion of some Russian scientists the systems of accumulation of credits, but not labour inputs are more attractive [12]. They are convenient for the organisation of the continuous education, do not depend on the form ofeducation and peculiarities of the national education systems of different countries which is important under the conditions of modern tendencies to their integration and creation of the single educational space. In this case the level of credit points out the complexity and the depth of knowledge, as well as the ability of independently use them on practice (skills and abilities). Consequently the question of quantitativeassessment of one creditin hours (general or academic) turns out to besecondary and depends on different forms of education (on-site, remote, external). The ways of control of the results of acquiring education programme (tests, exams) fall out of the credit assessment as they arenot the results but only the procedures of controlof the acquired results.

The Russian legislation allows the higher education institutions to solve the question of conversion of traditional norms into credits. The experience of PFUR and other Moscow higher education institutions shows that the transfer from hours to credits in the education process simplifies the implementation of module systems, ratings, formation of individual education ways by individual students [13]. Experience exchange, assessment of positive and negative results of the experiment is needed. For example, the scientific work cannot be measured in hours due to its creative nature. If two students acquire education material with different time of several hours, it doesn't mean that similar difference will be present in the effectiveness of the scientific work: one of them will not be able to solve a scientific task at all. While implementation of the non-linear (asynchronous) model of education process the scientific component of the education programme should be paid a specialattention.

The increase of the specific gravity of the independent work will create, in our opinion, additional psychological 
problems. As the experience show, only a small part of students is psychologically ready for the display of the initiative and activesearch ad gathering of information for the studying disciplines, and is ready to acquire the method of its analytical understanding. Most of the students, especially junior students, for the years of study in the school got used to the overlearning of a text-book, the simplest reproduction of the teacher's story.

According to V. Senaneshko and N. Zhalina the students' formation on the basis of individual education programmesinfluences their personal motivation in education, and the development of the new more effective methods of the current control of knowledge contribute to the increase ofthe quality of acquiring disciplines [14]. This is difficult to be argued. However it should be noted that the modern non-linear (course-like) system of acquiring education programmes by the students of the most Russian higher education institutions gives the students no freedom of choice even of the special courses. Whiletransferring from the «synchronous» system according to which all the students of a certain speciality, major learn the disciplines in certain sequence, to the «asynchronous», according to which everyone forms an individual educational trajectory, there will appear a chaos and the quality of education will decrease. The case is not only in the insufficient development of the methods of students' independent work organisation, according to V. Senashenko and N. Zhalnina. There is also the inertia of social habits, general natural conventionalism of education institution. Here one should not be in a hurry, a thorough analysis of the results of implementation of federal state educational standards is needed.

The main advantage of the Russian education system is fundamental nature, scientific character, systematic nature and practical orientation. Consequently, the implementation of the credit system should be considered first of all from these positions.

Until the normative base of the work of Russian higher school is not changed, the credits of the Bologna process will come into conflict with the course-like system of education. It is possible that the special transfer period of coexistence of credits with the traditional education programmes will be needed. In any case the organisation of the education process becomes more complicated.

Another one methodological and organisation problem is the definition of the «weighting coefficients» of the disciplines cycles (B.1, B.2, B.3) in educationalprogrammes. The algorithmization of the B.1 cycle for the technical specialities or B.2 cycle for humanitarian specialities is quite simple. It is possible to unify the inner structure of the cycles and define the structure of each disciplineaccording to the types of activities: classes (lectures, practical exercises, laboratory classes and term papers, tests). All this should be fixed in credits, which describe everycourse of study, every discipline and finally defines the labour efforts of the educational programme. The Ministry of education of the Russian Federation offered a simplified method of conversion of the labour efforts of the educational process into credits (letter of the Ministry of Education of Russia of 28.11.2002 \#14-52-988ин(13). According to this method the academic year lasts for 52 weeks, student's holidays consist of 2 weeks in winter and 8 weeks in summer. Two more weeks comprise of other different holidays. All types of education work including examination period, take 40 weeks. If we equal this amount of academic time to 60 credits as it is made in European ECTS system, 4 days of the academic week will be equal to one credit. The education during one academic year will comprise 60 conditional credits. No changes if the organisation of education process is needed in that case.

More difficult is to calculate the credits of the profile disciplines - the so-called component of curriculum of a higher education institution. What should one do with the methodological approaches and views of different schools in humanitarian sciences (philosophy, social science, politology, culturology)? Despite the ideological pluralism each country will probably prefer their own classics of science and culture.

The second level of ECTS use differs from the first one. In the first case the basis of education process is hours, in the second case it is credits. In order to do this the following is needed:

1. To develop curricula of new type;

2. To introduce into the education practice new working programmes of disciplines in which the content is expressed and controlled it credits;

3. To create a system of valid tests of knowledge, skills and abilities control;

4. To set correspondence of the credit system and indices of education cost and teachers' salary.

G. Tkach and V. Chistokhvalov think thatno system of marks can solve all the problems simultaneously. In any case the information represented by the extracts of the achievement sheet should represent the real but not supposed or ideal situation, and the ECTS system should contribute to the objective "reference" of marks of the sending and accepting higher education institutions. Since the setting of «reference» - of not only marks but the educational programmes and qualifications - for their comparison and recognition serves as one of the main reasons for introducing of the unified Diploma Supplement, use of unified scale of marks in it becomes the main condition for the achievement of that goals [15]. 
Now due to the accreditation or licensing of the direction, the specialities of a private higher education institution, the expert will arrive and will check everything when there are no criteria and everything is expressed in general words. The organisation of education process in the private education organisation of higher education includes a number of specific features which take into account the content of students and social state of their parents, motives for education of students in education organisation of this type, their value orientations, based on the characteristics of education process, rights and obligations of students.

The characteristic features of education process in this education organisations are intensive study which allows to provide the preparation of the students according to their majors while performing the federal state standards of higher education.

Private education organisation of higher education implicitly has more opportunities for formation and development of the creative personality. We think that this should contain the main moral-political and economic proof of this phenomenon in education.

The solving of the main problems of education process organisation in private higher education institutions within the frameworks of approaches which are traditional for the state higher education organisations, turns out to be inappropriate for the private ones.

In order to increase the education quality they attract highly qualified teachers from other higher education organisations who cannot deliver a course of lectures for the period pointed in the curriculum.

The experts of the the Federal Agency for Supervision in Education and Science give negative reports and the private education organisation of higher education gets no state accreditation even when having professionally-social accreditation for that UGN.

B. Beisbord points out that the non-commercial sector is represented as the respond to the inability of state structures to satisfy the total demand for the public goods and first of all in the social sphere [16].

The former deputy minister of education of Malta in his monograph "Education on Malta" underlines that the private sector "can provide educational services to its client faster, more directly and more effective than the state sector since private schools serve their clients directly compared to the red-tape state system, they are free of those national obligations which are present in the state and government. Since the private schools mainly function independently, they are not burdened with the state bureaucracy, they can better feel the market demand and deliver "goods" faster and sometimes more effectively than more complicated state system" [17].

V.V. Zyryanov and E. V. Karavaeva think that for the past several years the ministry of education and science of the Russian Federation leads intransparent policy of use of Credit system (does it correspond to the ECTS system\&) [18].

Yu. D. Artamonova and A. L. Demchuk offer the higher education institutions to explain the teachers the meaning of the concept of "recognition" and its connection with the competence approach and the idea of credits [19].

\section{Conclusion}

Thus, while developing the concept the system of credits for the Russian higher school it is important to discuss the principles of the credits assessment of the content of education programme on the basis of planning of results and its acquiring. The higher education institutions should be given an opportunity to develop experimental educational standards within the frameworks of the cycle (and probably course-like) structure of the federal state educational standards, providing the opportunity to navigate within the frameworks of the curriculum in order to increase the quality of higher education.

The main thing in the Bologna process if the combinability of the education programmes which provide academic mobility of the students and comparability of the quality of specialists training. How important is this problem for our students? We think that the problem of academic mobility is theoretic for Russia.

We should tend to the world tendencies and at the same time take into account inner needs and Russian mind set.

In the context of national safety interests of our country as well as in the context of the past changes of the international situation we can offer to the Ministry of education and science of the Russian Federation the idea of formation of the alternative Eurasian educational system of the CIS countries and Baltic states which is based on the Russian language. This will allow it to put back its former power, Russia will be able to strengthen its positions of the connecting link between the East and the West on the world stage.

\section{References}

Engines of Economic Growth. The Economic Impact of Boston Eight Research Universities on the Metropolitan Boston Area. Appleseed. 
2003.

Fleisher, B., Sabirianova, P. K. \& Wang X. (2005). Returns to Skills and the Speed Evidence from Central and Eastern Europe, China, and Russia. Journal of C Economics 33(2), 351-370.

Stepanov V.I. (2013). Problems of Ensuring Higher Education Quality within the Bologna Process. Tomsk State Pedagogical University Bulletin, 6, 27.

Memorandum of Higher Education in the European Community. Commission of the European Communities. Brussels. 1991.

The European Higher Education Area. Joint Declaration of the Ministers of Education. Bologna. 1999. 19 June.

Grudzinsky, A.O. \& Bedniy, A.B. (2010). University knowledge transfer for sustainable growth. Alma mater, 09, 26.

The Bologna Process 2020 The European Higher Education Area in the new decade: Communiquè of the Conference of European Ministers Responsible for Higher Education (2009). Leuven and Louvain-la-Neuye, 28-29 April 2009. High education in Russia, 7, 156-162.

Grebnev, L. (2004). Russia in Bologna Process: Middle of the Long Way. Higher Education in Russia, 4, 6.

Federal Law «On Education in Russian Federation». M.: INFRA-M, 2013. p.6.

Ivanova, V.I. (2006). On Some Normative Contradictions in Connection of Realizing Bologna Ideas in Russia, International Public and Private Law, 4, 18-24.

Gazaliev, A.M. \& Pak, Y.N. (2011). Kazakhstan Higher School in Bologna Process Context. Alma mater, 6, 16.

Chuchalin, A. \& Boev, O. (2004). Credit-Rating System. Higher Education in Russia, 3, 35.

Chistokhvalov, V. (2004). Credits Enter Russian Higher School. Higher Education in Russia, 4, 32 - 33.

Senashenko, V. \& Zhalnina, N. (2004). Quality of Higher Education and Credit System. Higher Education in Russia, 5, 15.

Tkach, G. \& Chistokhvalov, V. (2006). Diploma Supplement. Higher Education in Russia, 1, 69.

Weisbrod, B. (1998). The commercialism dilemma of the nonprofit sector. J. of policy analysis . Management, 17(2), 164-174.

Zammit, M. J. (1992). Education in Malta. Studia Editions, Valletta, Malta.

Zyryanov, V.V. \& Karavayeva, E.V. (2013). «Painful Points» of Transition. Tasks, Criteria and Results of Monitoring Effectiveness of Federal State Educational Standard in Russian Higher Institutions. Accreditation in Education, 64, 32.

Artamonova, Y.D. \& Demchuk, A.L. (2012). The Development of Academic Mobility and Federal State Education Standard. Higher Education in Russia, 12, 95. 